\title{
Marinade with alkaline solutions for the improvement of pork quality
}

\author{
Viviane Maria Oliveira dos Santos ${ }^{(1)}$, Fabiana Ribeiro Caldara(1), Leonardo de Oliveira Seno(1), \\ Gelson Luis Dias Feijó(2), Ibiara Correia de Lima Almeida Paz ${ }^{(1)}$, Rodrigo Garófallo Garcia ${ }^{(1)}$, \\ Irenilza de Alencar Nääs( ${ }^{(1)}$, and Ângela Dulce Cavenaghi Altemio(3)
}

\begin{abstract}
(1)Universidade Federal da Grande Dourados (UFGD), Faculdade de Ciências Agrárias, Rodovia Dourados-Ithaum, Km 12, CEP $79804-970$ Dourados, MS. E-mail: viviane.vmos@gmail.com, fabianacaldara@ufgd.edu.br, leonardoseno@ufgd.edu.br, ibiarapaz@ufgd.edu.br, rodrigogarcia@ufgd.edu.br, irenilza@gmail.com (2)Embrapa Gado de Corte, Avenida Rádio Maia, no 830, Vila Popular, Caixa Postal 154, CEP 79106-550 Campo Grande, MS. E-mail: gelson@cnpgc.embrapa.br (3)UFGD, Faculdade de Engenharia, Rodovia Dourados-Ithaum, Km 12, CEP 79804-970 Dourados, MS. E-mail: angelaaltemio@ufgd.edu.br
\end{abstract}

Abstract - The objective of this work was to evaluate the effects of alkaline solution marinades on the characteristics of pork subjected to post-mortem $\mathrm{pH}$ decrease in pig muscle. The $\mathrm{pH}$ of carcasses was measured in a commercial slaughterhouse $(\mathrm{n}=526), 45$ min after slaughtering $\left(\mathrm{pH}_{45}\right)$ and, then, the carcasses were divided into the groups with $\mathrm{pH}_{45} \leq 5.7$ or $\mathrm{pH}_{45}>5$.7. Ten samples of the longissimus dorsi muscles of each group were collected and distributed in an entirely randomized design, in a $2 \times 4$ factorial arrangement, with two conditions $\left(\mathrm{pH}_{45} \leq 5.7\right.$ or $\left.\mathrm{pH}_{45}>5.7\right)$, and four marinade solutions: TC, no marinade; TM1, sodium bicarbonate and sodium chloride; TM2, sodium tripolyphosphate and sodium chloride; TM3, sodium bicarbonate, sodium tripolyphosphate and sodium chloride. There was no interaction between $\mathrm{pH}_{45}$ of the meat and the marinade treatments. Meat with $\mathrm{pH}_{45} \leq 5.7$ showed higher values for lightness, and for purge loss (PL), exudate loss (EL), cooking loss (CL) and shear force (SF). Marinating increased the $\mathrm{pH}$, reduced the lightness, EL, CL and SF, and improved tenderness, juiciness and flavor of meat. Marinades with solutions containing chloride, bicarbonate, and sodium tripolyphosphate are effective in the improvement of pork quality, making physical characteristics of marinated meat similar to those of fresh pork, as a consequence of accelerated postmortem glycolysis.

Index terms: Sus scrofa, meat color, PSE meat, sodium bicarbonate, sodium chloride, sodium tripolyphosphate.

\section{Marinados com soluções alcalinas para a melhoria da qualidade da carne suína}

\begin{abstract}
Resumo - O objetivo deste trabalho foi avaliar os efeitos de marinadas com soluções alcalinas sobre características da carne de porco submetida a quedas do $\mathrm{pH}$ post-mortem, em músculo de porco. $\mathrm{O} \mathrm{pH}$ das carcaças foi medido em abatedouro comercial $(\mathrm{n}=526)$, aos 45 min pós-abate $\left(\mathrm{pH}_{45}\right)$ e, em seguida, as carcaças foram divididas em grupos com $\mathrm{pH}_{45} \leq 5,7$ ou $\mathrm{pH}_{45}>5,7$. Dez amostras do músculo longissimus dorsi de cada grupo foram coletadas e distribuídas em delineamento inteiramente casualizado, em arranjo fatorial $2 \times 4$, com duas condições $\left(\mathrm{pH}_{45} \leq 5,7\right.$ ou $\left.\mathrm{pH}_{45}>5,7\right)$ e quatro soluções de marinação: TC, controle sem marinação; TM1, bicarbonato de sódio e cloreto de sódio; TM2, tripolifosfato de sódio e cloreto de sódio; TM3, bicarbonato de sódio, tripolifosfato de sódio e cloreto de sódio. Não houve interação entre o $\mathrm{pH}_{45}$ da carne e os tratamentos marinados. As carnes com $\mathrm{pH}_{45} \leq 5,7$ apresentaram maior luminosidade, perda por purga (PP), perda de exsudato (PE), perda de peso por cozimento (PC) e força de cisalhamento (FC). A marinação aumentou o $\mathrm{pH}$ da carne, reduziu a luminosidade, PE, PC e FC, e melhorou a maciez, suculência e palatabilidade. As marinadas com soluções alcalinas de cloreto, bicarbonato e tripolifosfato de sódio são eficazes no melhoramento da qualidade da carne suína, o que torna as características físicas das carnes processadas com marinadas semelhantes às da carne in natura, em consequência da acelerada glicólise post-mortem.
\end{abstract}

Termos para indexação: Sus scrofa, cor da carne, carne PSE, bicarbonato de sódio, cloreto de sódio, tripolifosfato de sódio.

\section{Introduction}

The need to obtain swine (Sus scrofa L.) genetic strains with a high percentage of lean meat brought, as a consequence, animals that are more susceptible to stress, and final products with quality problems, such as pale, soft, exudative (PSE) meat. The main cause of the increase of PSE meat is the accelerated breakdown of muscle glycogen following slaughter, which leads to an increase of lactic acid and a consequent, rapid

Pesq. agropec. bras., Brasília, v.47, n.11, p.1655-1662, nov. 2012 
decrease of the muscle $\mathrm{pH}$. The combination of low $\mathrm{pH}$ and excessive muscle temperature promotes a greater denaturation of muscle proteins, reducing their capacity and strength for water retention (Castrillón et al., 2007; Shen et al., 2008), which influences the final product lightness (Kuo \& Chu, 2003).

PSE meat is a serious quality problem for pork industry due to its unattractive appearance and to high-water losses during processing, which make it inappropriate for consumers and processing industries. It specifically affects cuts of higher commercial value, such as loin and ham. PSE incidence has been reported worldwide to range from 10 to $50 \%$ (Cassens, 2000; Culau et al., 2002; Bridi et al., 2006; Maganhini et al., 2007; Adzitey \& Nurul, 2011).

Thus, both rapid detection of PSE meat and the search for methods that can minimize it are of fundamental importance to the pig industry. Research has confirmed the effectiveness of some ingredients in improving water holding capacity and flesh color. Sodium chloride and polyphosphates are the most studied, and they are usually combined to exploit their synergistic effects (Sheard \& Tali, 2004; Erdogdu et al., 2007). Other studies also support the use of sodium bicarbonate to minimize the presence of PSE in pork (Sindelar et al., 2003; Sheard \& Tali, 2004).

Since the rapid decline in postmortem muscle $\mathrm{pH}$ provides pork with low-water retention capacity, marinating seems to be an attractive alternative to minimize this problem.

The objective of this work was to evaluate the effects of alkaline solution marinades on the characteristics of pork subjected to post-mortem $\mathrm{pH}$ decrease in pig muscle.

\section{Materials and Methods}

The experiment was conducted at the Universidade Federal de Grande Dourados (UFGD), Dourados, MS, Brazil, in September 2011. Meat samples used in this analysis were obtained from a commercial slaughterhouse located in the same county, which has the capacity to slaughter about 2,500 heads per day. The animals used in this research were from Topigs genetic strain, weighting, in average, $120 \mathrm{~kg}$ per head. A visit to the slaughterhouse was made for the selection and collection of samples, and the $\mathrm{pH}$ of 526 pig carcasses was measured $45 \mathrm{~min}$ after slaughter $\left(\mathrm{pH}_{45}\right)$.
Assessments of $\mathrm{pH}_{45}$ were performed using a mobile pHmeter Testo 205, (Lenzkirch, Germany) connected to a thin probe tip, inserted in the center of the longissimus dorsi of the left half, between the $12^{\text {th }}$ and $13^{\text {th }}$ thoracic vertebrae. The carcasses were separated into two distinct groups, one with $\mathrm{pH}_{45} \leq 5.7$, as a possible indicative of PSE meat (Castrillón et al., 2007; Chen et al., 2010), and the other with $\mathrm{pH}_{45}>5$.7. From the total of evaluated carcasses, 10 with $\mathrm{pH}_{45} \leq 5.7$ and 10 with $\mathrm{pH}_{45}>5.7$ were selected for comparison. After 24 hours of cooling in the slaughterhouse refrigerator at $2^{\circ} \mathrm{C}$, the final $\mathrm{pH}\left(\mathrm{pH}_{24}\right)$ of the selected carcasses was determined. They were deboned, and $45 \mathrm{~cm}$ length samples of the longissimus dorsi muscle from the left-half of each carcass were collected, transported in coolers to the Laboratório de Tecnologia de Carnes of the UFGD, and immediately processed for the evaluations.

Samples were distributed in a completely randomized $2 \mathrm{x} 4$ factorial design, with two meat types $\left(\mathrm{pH}_{45} \leq 5.7\right.$ and $\mathrm{pH}_{45}>5.7$ ) and four marinating treatments: CT, nonmarinated control; TM1, sodium bicarbonate and sodium chloride solution; TM2, sodium tripolyphosphate and sodium chloride solution; and TM3, sodium bicarbonate, sodium tripolyphosphate and sodium chloride solution. The $45 \mathrm{~cm}$ loins were divided into four parts of approximately $10-\mathrm{cm}$ length, discarding the ends, and each one was randomly chosen to be one of the treatments. Each $10 \mathrm{~cm}$ piece was divided into four parts of approximately $2.5 \mathrm{~cm}$ for physical and sensory evaluations. Thus, each loin received the four treatments, totaling 10 replicates per treatment.

Ingredients for the marinating solutions were mixed in water at $4^{\circ} \mathrm{C}$, and the $\mathrm{pH}$ of the solutions was measured. Prepared to achieve $10 \%$ brine, the solutions were then applied to meat (Table 1).

Immediately prior to marinating, samples were weighed. Marinating was carried out by injection with a hand brine injector with a salt solution of approximately $10 \%$ of the initial weight of the samples, trying to spread the mixture evenly.

After injection, the control and marinated samples were weighed, individually packed in plastic bags, and stored under refrigeration at $4^{\circ} \mathrm{C}$ for 24 hours, for equalization of the solution. They were reweighed after this period. The difference (\%) corresponded to the purge loss (PL) during the equalization of the solution 
injected into meat. All samples, except for those for exudate loss analysis, were vacuum-packed separately, and stored under refrigeration at $4{ }^{\circ} \mathrm{C}$ for 48 hours before evaluation.

Samples for exudate loss analysis were weighed, packed in polystyrene trays, wrapped with plastic wrap and stored at $4 \pm 1^{\circ} \mathrm{C}$ for 48 hours. After these procedures, they were reweighed, and exudation loss (EL) determined. Results were expressed as percentage (Garcia et al., 2010).

Before and after marinating, samples were evaluated for color after the muscle surface exposition to ambient air for 30 min (blooming time) (Rosa et al., 2001). The evaluation of the discoloration was done using a portable colorimeter Minolta CR 410, using the CIELab scale $-\mathrm{L}^{*}$ (lightness), a* (redness), and $b^{*}$ (yellowness) -, with D65 illuminant (light source) and $10^{\circ}$ observer angle. Measurements were made at three different points on the sample surface, taking the average as the determined value. The samples were weighed and baked in an electric oven at $300^{\circ} \mathrm{C}$, reaching an internal temperature of $80^{\circ} \mathrm{C}$, and checked using a calibrated hand-held digital thermometer. After cooking, they were cooled to room temperature and reweighed. Percentage of CL was determined by the difference between the initial and final weights.

To determine meat tenderness (shear force, SF), six $13 \mathrm{~mm}$ diameter cylinders were taken parallel to the muscle fibers from the same samples used to evaluate the CL. Shear force was measured using a texture meter TA. XT2i, (Stable Micro Systems) with a Warner-Bratzler blade moving with a descent speed of $500 \mathrm{~mm}$ per minute.

Sensory evaluations were performed for meat tenderness, juiciness and flavor, based on a nine-point hedonic scale, using a trained panel of seven tasters, according to Kauffman et al. (1993).

Table 1. Composition and $\mathrm{pH}$ of brines used in the marinating process of normal and PSE pork.

\begin{tabular}{lccr}
\hline Ingredient & TM 1 & TM 2 & TM 3 \\
& -------------- \\
\hline Water & 90.42 & 90.10 & 90.10 \\
Sodium chloride & 6.60 & 6.60 & 4.62 \\
Sodium bicarbonate & 1.98 & - & 1.98 \\
Sodium tripolyphosphate & - & 3.30 & 3.30 \\
Total & 100.00 & 100.00 & 100.00 \\
\hline pH & 8.02 & 10.34 & 8.97 \\
\hline
\end{tabular}

The variables $\mathrm{PL}, \mathrm{SF}, \mathrm{CL}, \mathrm{pH}_{24}$ and color had the model assumptions met (normality and homoscedasticity), and were tested using Tukey's mean. EL values did not meet the assumptions of the model, and the Kruskal Wallis test was applied to them. For EL, CL and SF, the mean contrast test was applied. The Kruskall Wallis test was applied to the nonparametric variables (tenderness, flavor and juiciness). Pearson's correlation was applied to evaluate the relationship between physical and sensory characteristics. For all analyses, a 5\% level of significance was considered. Statistical calculations were done using the SAS 9.2 computer package, applying the general linear model (GLM).

\section{Results and Discussion}

No interaction was found between the $\mathrm{pH}_{45}$ of meat and the marinating treatments, thus the main effects were discussed separately.

No difference was found between the $\mathrm{pH}_{24}$ of meat due to the different groups of $\mathrm{pH}_{45}$ (Table 2). However, the $\mathrm{pH}_{24}$ is not a reliable indicator of possible changes in meat quality such as the PSE condition (Henckel et al., 2002), except for extreme values $(<5.3)$ (Bowker et al., 1999). Culau et al. (2002) assessed the effect of halothane genotype on pork quality and found differences among genotypes as to the initial meat $\mathrm{pH}$ (5.91, 5.71 and 5.68, respectively); however, this difference did not appear after rigor mortis set in, reaching an average $\mathrm{pH}$ of 5.45 .

Meat with $\mathrm{pH}_{45} \leq 5.7$ showed significantly higher L* (1.53 units) than meat with $\mathrm{pH}_{45}>5.7$ before marinating. However, this difference was not observed after marinating, indicating that this process provided partial recovery of meat color. The amount of free water in meat can affect its lightness. Meat with lower water-holding capacity looks paler (colorness) than normal meat, since free water reflects lights in a diffuse manner (Kuo \& Chu, 2003). However, the L* values found were lower than those reported in the literature for the PSE pork (America Meat Science Association, 2001; Ramos \& Gomide, 2007).

It is difficult to classify pork based only on color factors. There is wide a variation in the $L^{*}$ value criteria used to separate normal and PSE pork. The American Meat Science Association (America Meat Science Association, 2001) considers the L* values between 49 and 60 within the normal standards of 
pork quality; whereas, for Ramos \& Gomide (2007), the $L^{*}$ values of normal meat range between 45 and 53. This difference may be attributed to intrinsic factors, such as the genetic strain of the animals, or operational factors, such as equipment used for measurement, calibration of the equipment, angle and light sources, standardization of the samples and differences in methodology.

No differences in the $\mathrm{L}^{*}$ or $\mathrm{b}^{*}$ intensities were found in meat after marinating, regardless of their $\mathrm{pH}_{45}$, although some studies report that increasing $\mathrm{pH}$ implies in a decrease in meat L* (Brewer et al., 2006; Chen et al., 2010). Regardless of the treatment and $\mathrm{pH}_{45}$, meat $\mathrm{pH}_{24}$ before injection with the solutions remained below 5.5. No difference in meat $\mathrm{pH}$ after marination was found between treatments, although marinating promoted an increase of up to $9 \%$ in meat $\mathrm{pH}$. Similar increases in meat $\mathrm{pH}$ after marinating with polyphosphates and sodium bicarbonate have been reported in the literature (Sindelar et al., 2003; Sheard \& Tali, 2004; Sheard et al., 2005).

Marinating with TM3 reduced $\mathrm{a}^{*}$ of pork loin samples. This effect was not observed when TM1 and TM2 salts were used separately, which led to the inference that the results were promoted by a synergistic action between them, with an indication that the presence of sodium tripolyphosphate in the marinade

Table 2. Acidity, lightness ( $\left.\mathrm{L}^{*}\right)$, redness $\left(\mathrm{a}^{*}\right)$ and yellowness $\left(b^{*}\right)$ of pork with different $\mathrm{pH}_{45}(\leq 5.7$ and $>5.7)$, before and after marinating with different solutions ${ }^{(1)}$.

\begin{tabular}{|c|c|c|c|c|c|c|c|}
\hline \multirow[t]{2}{*}{ Evaluation } & \multicolumn{4}{|c|}{ Treatment } & \multicolumn{2}{|c|}{$\mathrm{pH}_{45}$} & \multirow{2}{*}{$\begin{array}{l}\text { CV } \\
(\%)\end{array}$} \\
\hline & $\mathrm{TC}$ & TM1 & TM2 & TM3 & $>5.7$ & $\leq 5.7$ & \\
\hline & \multicolumn{7}{|c|}{$\mathrm{pH}_{24}$} \\
\hline Before & $5.47 \mathrm{~A}$ & $5.46 \mathrm{~B}$ & $5.45 \mathrm{~B}$ & 5.44B & 5.47 & 5.44 & 1.68 \\
\hline \multirow[t]{2}{*}{ After } & $5.47 \mathrm{Ab}$ & $5.81 \mathrm{Aa}$ & $5.88 \mathrm{Aa}$ & $5.98 \mathrm{Aa}$ & 5.88 & 5.87 & 4.13 \\
\hline & \multicolumn{7}{|c|}{$\mathrm{L}^{*}$} \\
\hline Before & 47.28 & 47.03 & 48.30 & 48.69 & $47.06 \mathrm{Ab}$ & 48.59Aa & 6.25 \\
\hline \multirow[t]{2}{*}{ After } & 46.02 & 46.04 & 45.63 & 45.45 & $45.37 \mathrm{Ba}$ & $46.20 \mathrm{Ba}$ & 7.34 \\
\hline & \multicolumn{7}{|c|}{$a^{*}$} \\
\hline Before & $13.08 \mathrm{~A}$ & $12.98 \mathrm{~A}$ & $12.91 \mathrm{~A}$ & $12.92 \mathrm{~A}$ & 13.14 & 12.81 & 5.66 \\
\hline \multirow[t]{2}{*}{ After } & $12.67 \mathrm{Aa}$ & $12.27 \mathrm{Ba}$ & $12.03 \mathrm{Bab}$ & $11.94 \mathrm{Bb}$ & 12.40 & 12.05 & 6.69 \\
\hline & \multicolumn{7}{|c|}{$\mathrm{b}^{*}$} \\
\hline Before & 2.01 & 2.05 & 2.16 & 2.25 & 2.06 & 2.18 & 32.28 \\
\hline After & 3.14 & 3.07 & 2.71 & 2.61 & 2.83 & 2.93 & 42.54 \\
\hline
\end{tabular}

${ }^{(1)}$ Means followed by equal letters, lowercase in the same line and uppercase in the same column, do not differ by Tukey's test, at 5\% probability. TC, control, no marinating; TM1, sodium bicarbonate and sodium chloride; TM2, sodium tripolyphosphate and sodium chloride; TM3, sodium bicarbonate, sodium tripolyphosphate and sodium chloride. mixture may have influenced some variables in the tested meat. Most additives used in processing meat products may cause changes in color by modifying the $\mathrm{pH}$ and the state of myoglobin (Fernández-López et al., 2004). Decrease in the a* intensity of pig loins injected with tripolyphosphate and sodium chloride was observed by Daguer (2010).

$\mathrm{pH}_{24}$ meat was negatively correlated with the lightness and yellowness before $(r=-0.39 r=-0.42)$ and after $(\mathrm{r}=-0.31$ and $\mathrm{r}=-0.26)$ marinating, indicating that the lower the $\mathrm{pH}$, the higher the lightness and yellowness of meat, and that this condition is maintained even after the injection of brines containing bicarbonate, sodium chloride and polyphosphate. Lightness and yellowness were positively correlated before $(r=0.77)$ and after $(r=0.90)$ marinating, which indicates that paler meat is also yellower.

Meat with $\mathrm{pH}_{45} \leq 5.7$ showed a lower retention capacity of the injected solutions, losing $63 \%$ more liquid by purging (PL) than meat of the other group (Table 3). No difference was found in purge loss between the injected solutions, and the values are close to those found by Daguer (2010).

Exudation and cooking losses were also higher for meat with $\mathrm{pH}_{45} \leq 5.7$ than meat from the other group (30 and $13 \%$, respectively). Meat with $\mathrm{pH}_{45}>5.7$ showed $18.37 \%$ lower shear force (Table 3).

Kuo \& Chu (2003) reported 50\% higher exudate loss in PSE pork. The highest water losses from PSE meat are related to rate and extent of postmortem $\mathrm{pH}$ decrease, which has a substantial impact on meat quality, especially in water-holding capacity, affecting sensory and technological properties (Toldrá, 2003). According to researchers, meat with $\mathrm{pH}_{45}$ lower than 5.8 (Kauffman et al., 1993; Culau et al., 2002), L * values greater than 50, and water loss greater than $6 \%$ can be considered as PSE meat (Warner et al., 1997; Bridi et al., 2006). Considering this classification, the meat from the $\mathrm{pH}_{45} \leq 5.7$ treatment of this experiment would not fulfill the PSE conditions, although it is clear that its physical properties, particularly its ability to retain water, have been harmed by the higher drop rate of postmortem $\mathrm{pH}$.

TM3 marinade caused $37.9 \%$ decrease of meat exudation loss in comparison with the nonmarinated treatment. However, CT, TM1, and TM2 did not differ from each other. These data confirm the synergistic effect of TM3, with positive results on pork characteristics, as evidenced by Bertram et al. (2008). Phosphate salts 
and brines are used in depolymerized muscle fiber myosin filaments, and help dissociating the act-myosin complex, increasing the dissolved protein (Bertram et al., 2008). In addition, they capture the negatively charged metal ions, leaving the actual charges free to bind water molecules, thereby increasing the capacity of meat to retain water (Xiong, 2005).

Cooking loss was reduced by 13 to $21 \%$ by marinating, with no difference between the solutions. Higher values were reported by Szerman et al. (2007) and Daguer et al. (2010), who found a reduction from 23 to $26 \%$ in cooking loss after marinating with sodium tripolyphosphate. The reduction in CL may be partially explained by the chemical interaction between water and proteins which occurs with marinating (Xiong, 2005). Phosphates increase the ionic strength of meat, decreasing weight loss by cooking, leading the exudative pork to achieve a similar performance as the normal raw meat.

Meat with $\mathrm{pH}_{45} \leq 5.7$ showed a higher shear force than the others, probably due to the higher percentage of moisture lost, from slaughter to cooking. However, considering the values obtained for both conditions of the $\mathrm{pH}_{45}$, the pork loins may be considered tender. For the National Pork Producers Council (1999), whose methodology was used in this study, the maximum value of shear force for pork to be considered tender is $31.4 \mathrm{~N}$.

Marinating decreased meat shear force by approximately $41 \%$. Sheard \& Tali (2004) found $50 \%$ reduction in shear force, indicating a significant improvement in tenderness of pork marinated with alkaline brines. The values obtained in the present study are close to the range reported in the literature (14.31 to $28.34 \mathrm{~N})$ for pork marinated with tripolyphosphate and sodium chloride (Sindelar et al., 2003; Daguer, 2010).
Marinating with sodium tripolyphosphate and sodium chloride improves the texture of meat fibers, making them softer (Szerman et al., 2012). In general, one of the most obvious mechanisms to reduce shear force after application of the brine is the swelling and relaxation of the muscle fibers. This is enhanced with the use of brines derived from alkaline salts, especially when in association (Sheard \& Tali, 2004; Szerman et al., 2007; Xu et al., 2009).

Sodium chloride plays a decisive role in meat tenderness, by acting in the extraction and solubilization of muscle proteins and fat emulsification, contributing to increased water-retention capacity, improving meat softness and texture (Baublits et al., 2006). The weakening of myofibrils by use of sodium bicarbonate is not well understood, although it is clear that the reduction in shear force is similar to that achieved by the use of sodium phosphate (Bertram et al., 2008), as evidenced in the present study. Solutions of sodium tripolyphosphate act in the muscle fiber, and increase meat $\mathrm{pH}$, providing more efficient water absorption by the muscle, reducing exudation loss during storage, and improving various properties of meat (Lemos et al., 1999).

Meat shear force was inversely proportional to its $\mathrm{pH} 48$ hours after marinating. These results agree with those of other researchers, showing that alkaline brines improve the physical characteristics of beef by raising its pH (Sheard \& Tali, 2004; Baublits et al., 2006; Szerman et al., 2007; Bertram et al., 2008).

Comparing the physical characteristics from marinated meat of the group with $\mathrm{pH}_{45} \leq 5.7$ with those of fresh normal meat $(\mathrm{pH}>5.7)$ (nonmarinated - CT), it was observed that marinating recovered their quality (SF, EL and CL), making them similar or better than normal, nonmarinated meat (Table 4). Marinating of meat with low $\mathrm{pH}_{45}\left(\mathrm{pH}_{45} \leq 5.7\right)$ caused up to $37 \%$

Table 3. Purge loss (PL), exudate loss (EL), cooking loss (CL) and shear force (SF) of pork with different $\mathrm{pH}_{45}(\leq 5.7$ and $>5.7)$ and marinating solutions ${ }^{(1)}$.

\begin{tabular}{|c|c|c|c|c|c|c|}
\hline \multirow[t]{2}{*}{ Character } & \multicolumn{4}{|c|}{ Treatment } & \multicolumn{2}{|c|}{$\mathrm{pH}_{45}$} \\
\hline & $\mathrm{TC}$ & TM1 & TM2 & TM3 & $>5.7$ & $\leq 5.7$ \\
\hline PL (\%) & - & $2.26 \pm 1.0$ & $2.26 \pm 0.8$ & $2.27 \pm 0.9$ & $1.71 \pm 0.8 \mathrm{~b}$ & $2.79 \pm 0.7 \mathrm{a}$ \\
\hline EL (\%) & $3.77 \pm 2.1 \mathrm{a}$ & $3.44 \pm 2.0 \mathrm{ba}$ & $3.66 \pm 2.0 \mathrm{a}$ & $2.34 \pm 1.6 \mathrm{~b}$ & $2.87 \pm 2.0 \mathrm{~B}$ & $3.74 \pm 2.0 \mathrm{~A}$ \\
\hline CL (\%) & $29.51 \pm 2.9 \mathrm{a}$ & $25.52 \pm 4.3 b$ & $25.75 \pm 4.8 b$ & $23.15 \pm 5.6 \mathrm{~b}$ & $24.39 \pm 5.0 \mathrm{~B}$ & $27.58 \pm 4.4 \mathrm{~A}$ \\
\hline $\mathrm{SF}(\mathrm{N})$ & $42.75 \pm 9.8 \mathrm{a}$ & $24.12 \pm 6.9 b$ & $28.54 \pm 9.8 b$ & $22.65 \pm 2.9 \mathrm{~b}$ & $26.58 \pm 9.8 \mathrm{~B}$ & $32.56 \pm 12.7 \mathrm{~A}$ \\
\hline
\end{tabular}

${ }^{(1)}$ Means followed by equal letters, lowercase for treatment and uppercase for $\mathrm{pH}_{45}$, in the same line, do not differ by Tukey's test, at $5 \%$ probability. TC, control, nonmarinated pork. Marinated pork: TM1, sodium bicarbonate and sodium chloride; TM2, sodium tripolyphosphate and sodium chloride; TM3, sodium bicarbonate, sodium tripolyphosphate and sodium chloride. 
decrease in shear force. No differences were found for the exudate and cooking losses between meat with different initial $\mathrm{pH}$, showing that the injection of alkaline solutions containing bicarbonate, tripolyphosphate and sodium chloride, individually and in association approached the physical characteristics of meat with low, initial $\mathrm{pH}\left(\mathrm{pH}_{45}\right)$ to approach the quality standards of normal meat.

No significant effect was found either for meat tenderness, juiciness, or flavor between meat samples with different $\mathrm{pH}_{45}$ in the evaluation done by the sensory panel (Table 5). Since the water-retention capacity directly influences the sensory characteristics of meat, differences between them had been expected, especially for tenderness and juiciness, since meat with $\mathrm{pH}_{45} \leq 5.7$ had higher exudate and cooking losses. Although the instrumental analysis of tenderness detected a difference of shear force between meat samples with different $\mathrm{pH}_{45}$, this was not evident to the sensory panel, who found no differences. Moelich et al. (2003) found lower scores for meat of animals susceptible to stress, when evaluating juiciness; however, in the same study the meat flavor was not influenced by stressful conditions.

Table 4. Comparison of the shear force (SF), exudate loss (EL) and cooking loss (CL) between $\mathrm{pH}_{45}>5.7$ fresh pork (nonmarinated) and $\mathrm{pH}_{45} \leq 5.7$ marinated pork with different salt combinations ${ }^{(1)}$.

\begin{tabular}{lccccc}
\hline Character & $\mathrm{pH}_{45}>5.7$ & \multicolumn{2}{c}{$\mathrm{pH} \leq 5.7$ marinated pork } & \multirow{2}{*}{ p value } \\
\cline { 3 - 4 } & nonmarinated pork & $\mathrm{TM} 1$ & $\mathrm{TM} 2$ & $\mathrm{TM} 3$ & \\
\hline $\mathrm{SF}(\mathrm{N})$ & $37.85 \pm 8.2 \mathrm{a}$ & $26.97 \pm 8.1 \mathrm{~b}$ & $31.58 \pm 9.2 \mathrm{a}$ & $23.83 \pm 6.7 \mathrm{~b}$ & 0.006 \\
$\mathrm{EL}(\%)$ & $3.74 \pm 1.3$ & $4.19 \pm 1.6$ & $3.84 \pm 1.8$ & $2.76 \pm 1.3$ & 0.837 \\
$\mathrm{CL}(\%)$ & $28.43 \pm 2.2$ & $25.95 \pm 6.6$ & $27.38 \pm 6.8$ & $25.03 \pm 4.5$ & 0.246 \\
\hline
\end{tabular}

${ }^{(1)}$ Means followed by equal letters, in the same line, do not differ statistically by Tukey's test, at 5\% probability. TC, control, nonmarinated pork. Marinated pork: TM1, sodium bicarbonate and sodium chloride; TM2, sodium tripolyphosphate and sodium chloride; TM3, sodium bicarbonate, sodium tripolyphosphate and sodium chloride.
TM3 promoted better tenderness, whereas according to scores attributed by the tasters, meat treated with this solution was classified as tender to very tender, showing once again the synergistic effects of salts. Pork loins marinated with sodium chloride, and polyphosphates were considered even tenderer than the nonmarinated ones (Baublits et al., 2006). Marinating improved meat flavor, regardless of the solution used, and it was classified by the panelists as tasty to very tasty.

Marinating improved meat juiciness in comparison to the control, with no differences between solutions. Juiciness of marinated pork loins can be partly explained by the reduction of water loss through exudate and cooking, promoted by alkaline brines, which positively affected the sensory characteristics (Baublits et al., 2006; Smith \& Young, 2007; Sultana et al., 2008; Xu et al., 2009).

Negative correlations were observed $(p<0.01)$ between $\mathrm{pH}$ and EL (-0.41), SF (-0.38) and CL $(-0.35)$, indicating that lower meat $\mathrm{pH}$ decreases the water-retention capacity and increases the SF force required to break the fibers. Positive correlations $(\mathrm{p}<0.01)$ were found between meat $\mathrm{pH}$ and tenderness (0.30), juiciness (0.36), and flavor (0.39). However, despite significant, these correlations were low. Other studies have shown higher correlations between $\mathrm{pH}$ and tenderness (0.83) and juiciness (0.78) of marinated pork, as assessed by sensory panels (Sheard et al., 2005). The exudate loss and cooking loss were negatively correlated with tenderness $(-0.44$ and -0.54 , respectively) and juiciness ( -0.41 and -0.49 , respectively), showing that the capacity of meat to retain exudate during processing has a significant effect on the sensory parameters.

The positive correlation between shear force and the exudate and cooking losses explains the lower water-holding capacity reflected in tougher loins. According to Moelich et al. (2003), as more water is lost

Table 5. Sensory characteristics of pork with different $\mathrm{pH}_{45}(\leq 5.7$ and $>5.7)$, with or without marination in different solutions ${ }^{(1)}$.

\begin{tabular}{|c|c|c|c|c|c|c|}
\hline \multirow[t]{2}{*}{ Character } & \multicolumn{4}{|c|}{ Treatment } & \multicolumn{2}{|c|}{$\mathrm{pH}_{45}$} \\
\hline & TC & TM1 & TM2 & TM3 & $>5.7$ & $\leq 5.7$ \\
\hline Tenderness & $6.28 \pm 0.5 \mathrm{c}$ & $7.76 \pm 0.7 b$ & $7.90 \pm 0.6 \mathrm{ab}$ & $8.23 \pm 0.5 a$ & $7.66 \pm 0.9$ & $7.42 \pm 0.9$ \\
\hline Flavor & $6.24 \pm 0.4 b$ & $7.66 \pm 0.4 \mathrm{a}$ & $7.64 \pm 0.4 \mathrm{a}$ & $7.87 \pm 0.4 \mathrm{a}$ & $7.33 \pm 0.7$ & $7.38 \pm 0.8$ \\
\hline Juiciness & $5.73 \pm 0.6 b$ & $7.31 \pm 0.5 \mathrm{a}$ & $7.40 \pm 0.5 \mathrm{a}$ & $7.63 \pm 0.4 \mathrm{a}$ & $7.00 \pm 1.0$ & $7.04 \pm 0.8$ \\
\hline
\end{tabular}

${ }^{(1)}$ Means followed by equal letters, lowercase for treatment and uppercase for $\mathrm{pH}_{45}$, in the same line, do not differ by Tukey's test, at $5 \%$ probability. Treatment: TC, control, nonmarinated pork. Marinated pork: TM1, sodium bicarbonate and sodium chloride solution; TM2, sodium tripolyphosphate and sodium chloride solution; TM3, sodium bicarbonate, sodium tripolyphosphate and sodium chloride solutions. 
during meat processing, more cut-resistant it becomes. These authors found a correlation of $r=0.58$ between weight loss by cooking and shear force.

Tenderness (-0.68), juiciness (-0.57) and flavor $(-0.50)$ of meat were high and negatively correlated with shear force. Similar results were found by Moelich et al. (2003), who observed a negative correlation between shear force and tenderness when evaluated by a sensorial panel.

Juiciness, tenderness, and flavor were positively correlated. Together with tenderness, juiciness is one of the most desirable attributes for consumers (Xu et al., 2009). Meat with a higher degree of juiciness has a better acceptance by consumers, because it is tastier. Sheard et al. (2005), however, found a high and negative correlation between flavor and tenderness (-0.62) of pork loins marinated with sodium bicarbonate and sodium polyphosphate. These authors used commercial solutions (Kip and Kip vers), with the potential to improve the physical characteristics of meat, which proved to leave a residual unpleasant aftertaste. There were negative correlations between physical and sensory characteristics, showing the high efficiency of the sensory panel to evaluate pork quality.

\section{Conclusions}

1. Pork meat had its technological and sensory characteristics improved after marinating with alkaline solutions containing sodium bicarbonate, sodium tripolyphosphate, and sodium chloride, and this may be an efficient strategy for improving meat quality.

2 . The association of salts promotes a synergistic effect, boosting the results.

3. A sensory panel is efficient in evaluating pork meat quality.

\section{References}

ADZITEY, F.; NURUL, H. Pale soft exudative (PSE) and dark firm dry (DFD) meats: causes and measures to reduce these incidences - a mini review. International Food Research Journal, v.18, p.11-20, 2011.

AMERICAN MEAT SCIENCE ASSOCIATION. Meat evaluation handbook. Savoy: American Meat Science Association, 2001. $161 \mathrm{p}$.

BAUBLITS, R.T.; MEULLENET, J.F.; SAWYER, J.T.; MEHAFFEY, J.M.; SAHA, A. Pump rate and cooked temperature effects on pork loin instrumental, sensory descriptive and consumer-rated characteristics. Meat Science, v.72, p.741-750, 2006.

BERTRAM, H.C.; MEYER, R.L.; WU, Z.; ZHOU, X.; ANDERSEN, H.J. Water distribution and microstructure in enhanced pork. Journal of Agricultural and Food Chemistry, v.56, p.7201-7207, 2008.

BOWKER, B.C.; WYNVEEN, E.J.; GRANT, A.L.; GERRARD, D.E. Effects of electrical stimulation on early postmortem muscle $\mathrm{pH}$ and temperature declines in pigs from different genetic lines and halothane genotypes. Meat Science, v.53, p.125-133, 1999.

BREWER, M.S.; NOVAKOFSKI, J.; FREISE, K. Instrumental evaluation of $\mathrm{pH}$ effects on ability of pork chops to bloom. Meat Science, v.72, p.596-602, 2006.

BRIDI, A.M.; OLIVEIRA, A.R. de; FONSECA, N.A.N.; SHIMOKOMAKI, M.; COUTINHO, L.L.; SILVA, C.A. da. Efeito do genótipo halotano, da ractopamina e do sexo do animal na qualidade da carne suína. Revista Brasileira de Zootecnia, v.35, p.2027-2033, 2006.

CASSENS, R.G. Historical perspectives and current aspects of pork meat quality in the USA. Food Chemistry, v.69, p.357-363, 2000 .

CASTRILLÓN, W.E.; ZOOT, M.S.; FERNÁNDEZ, J.A.; RESTREPO L.F. Variables asociadas con la presentación de carne PSE (pálida, suave, exudativa) en canales de cerdo. Revista Colombiana de Ciencias Pecuarias, v.20, p.327-338, 2007.

CHEN, T.; ZHOU, G.H.; XU, X.L.; ZHAO, G.M.; LI, C.B. Phospholipase A2 and antioxidant enzyme activities in normal and PSE pork. Meat Science, v.84, p.143-146, 2010.

CULAU, P. de O.V.; LÓPEZ, J.; RUBENSAM, J.M.; LOPES, R.F.F.; NICOLAIEWSKY, S. Influência do gene halotano sobre a qualidade da carne suína. Revista Brasileira de Zootecnia, v.31, p.954-961, 2002.

DAGUER, H.; ASSIS, M.T.Q.M.; BERSOT, L. dos S. Controle da utilização de ingredientes não cárneos para injeção e marinação de carnes. Ciência Rural, v.40, p.2037-2046, 2010.

ERDOGDU, S.B.; ERDOGDU, F.; EKIZ, H.I. Influence of sodium tripolyphosphate (STP) treatment and cooking time on cook losses and textural properties of red meats. Journal of Food Process Engineering, v.30, p.685-700, 2007.

FERNÁNDEZ-LÓPEZ, J.; SAYAS-BARBERÁ, E.; PÉREZ-ALVAREZ, J.A.; ARANDA-CATALÁ, V. Effect of sodium chloride, sodium tripolyphosphate and $\mathrm{pH}$ on color properties of pork meat. Color Research and Application, v.29, p.67-74, 2004.

GARCIA, R.G.;FREITAS, L.W. de; SCHWINGEL,A.W.; FARIAS, R.M.; CALDARA, F.R.; GABRIEL, A.M.A.; GRACIANO, J.D.; KOMIYAMA, C.M.;ALMEIDAPAZ, I.C.L. Incidence and physical properties of PSE chicken meat in a commercial processing plant. Brazilian Journal of Poultry Science, v.12, p.233-237, 2010.

HENCKEL, P.; KARLSSON, A.; JENSEN, M.T.; OKSBJERG, N.; PETERSEN, J.S. Metabolic conditions in porcine longissimus muscle immediately pre-slaughter and its influence on peri- and post mortem energy metabolism. Meat Science, v.62, p.145-155, 2002. 
KAUFFMAN, R.G.; CASSENS, R.G.; SCHERER, A.; MEEKER, D.L. Variations in pork quality: History, definition, extent, resolution. Swine Health and Production, v.1, p.28-34, 1993.

KUO, C.C.; CHU, C.Y. Quality characteristics of Chinese sausages made from PSE pork. Meat Science, v.64, p.441-449, 2003.

LEMOS, A.L.S.C.; NUNES, D.R.M.; VIANA, A.G. Optimization of still-marinating process of chicken parts. Meat Science, v.52, p.227-234, 1999.

MAGANHINI, M.B.; MARIANO, B.; SOARES, A.L.; GUARNIERI, P.D.; SHIMOKOMAKI, M.; IDA, E.I. Carnes PSE (pale, soft, exudative) e DFD (dark, firm, dry) em lombo suíno numa linha de abate industrial. Ciência e Tecnologia de Alimentos, v.27, p.69-72, 2007.

MOELICH, E.I.; HOFFMAN, L.C.; CONRADIE, P.J. Sensory and functional meat quality characteristics of pork derived from three halothane genotypes. Meat Science, v.63, p.333-338, 2003.

NATIONAL PORK PRODUCERS COUNCIL. Pork quality targets. 1999. Available at: <http://www.nppc.org/facts/targets.html>. Accessed on: 12 Sept. 2010.

RAMOS, E.M.; GOMIDE, L.A.M. Avaliação da qualidade de carnes: fundamentos e metodologias. Viçosa: UFV, 2007. 599p.

ROSA, A.F.; SOBRAL, P.J. do A.; LIMA, C.G. de; GOMES, J.D.F. Determinação das características físico químicas da carne de suínos em fase de crescimento. Revista TeC Carnes, v.3, p.13-18, 2001.

SHEARD, P.R.; NUTE, G.R.; RICHARDSON, R.I.; WOOD, J.D. Effects of breed and marination on the sensory attributes of pork from Large White and Hampshire-sired pigs. Meat Science, v.70, p.699-707, 2005.

SHEARD, P.R.; TALI, A. Injection of salt, tripolyphosphate and bicarbonate marinade solutions to improve the yield and tenderness of cooked pork loin. Meat Science, v.68, p.305-311, 2004.

SHEN, Q.W.W.; GERRARD, D.E.; DU, M. Compound C, an inhibitor of AMP-activated protein kinase, inhibits glycolysis in mouse longissimus dorsi postmortem. Meat Science, v.78, p.323-330, 2008.

SINDELAR, J.J.; PROCHASKA, F.; BRITT, J.; SMITH, G.L.; MILLER, R.K.; TEMPLEMAN, R.; OSBURN, W.N. Strategies to eliminate atypical flavours and aromas in sow loins. I. Optimization of sodium tripolyphosphate, sodium bicarbonate, and injection level. Meat Science, v.65, p.1211-1222, 2003.

SMITH D.P.; YOUNG L.L. Marination pressure and phosphate effects on broiler breast fillet yield, tenderness, and color. Poultry Science, v.86, p.2666-2670, 2007.

SULTANA, A.; NAKANISHI, A.; ROY, B.C.; MIZUNOYA, W.; TATSUMI, R.; ITO, T.; TABATA, S.; RASHID, H.; KATAYAMA, S.; IKEUCHI, Y. Quality improvement of frozen and chilled beef biceps femoris with the application of salt-bicarbonate solution. Asian - Australasian Journal of Animal Sciences, v.21, p.903-911, 2008.

SZERMAN, N.; GONZALEZ, C.B.; SANCHO, A.M.; GRIGIONI, G.; CARDUZA, F.; VAUDAGNA, S.R. Effect of the addition of conventional additives and whey proteins concentrates on technological parameters, physicochemical properties, microstructure and sensory attributes of sous vide cooked beef muscles. Meat Science, v.90, p.701-710, 2012.

SZERMAN, N.; GONZALEZ, C.B.; SANCHO, A.M.; GRIGIONI, G.; CARDUZA, F.; VAUDAGNA, S.R. Effect of whey protein concentrate and sodium chloride addition plus tumbling procedures on technological parameters, physical properties and visual appearance of sous vide cooked beef. Meat Science, v.76, p.463-473, 2007.

TOLDRÁ, F. Muscle foods: water, structure and functionality. Food Science Technology International, v.9, p.173-177, 2003.

WARNER, R.D.; KAUFFMAN, R.G.; GREASER, M.L. Muscle protein changes post mortem in relation to pork quality traits. Meat Science, v.45, p.339-352, 1997.

XIONG, Y.L.L. Role of myofibrillar proteins in water-binding in brine-enhanced meats. Food Research International, v.38, p.281-287, 2005.

XU, S.Q.; ZHOU, G.H.; PENG, Z.Q.; ZHAO, L.Y.; YAO, R. The influence of polyphosphate marination on Simmental beef shear value and ultrastructure. Journal of Muscle Foods, v.20, p.101-116, 2009.

Received on May 3, 2012 and accepted on Octuber 23, 2012 